\title{
PERBEDAAN ANGKA KUMAN UDARA RUANG OPERASI SEBELUM DAN SESUDAH STERILISASI ULTRAVIOLET RSUD RATU ZALECHA
}

\author{
Luky Rinda Meiriana, Imam Santoso, Erminawati \\ Poltekkes Kemenkes Banjarmasin Jurusan Kesehatan Lingkungan \\ Jl. H. Mistar Cokrokusumo No.1A Banjarbaru Kalimantan Selatan 70714 \\ E-mail: lukyrinda@gmail.com
}

\begin{abstract}
Difference In The Number Of Airborne Operation Room Before And After UV Sterilization In Ratu Zalecha Martapura. Hospitals become one where the occurrence of environmental pollution, health problems or can be a place of disease transmission. The operating room is a potentially high room causing nosocomial infections in the hospital, especially surgical wound infections. Bacteriological qualities of the general surgery and inroom surgery room, the researchers assume that there are variations in different ratio rates on the stages of laboratories measurement results. So it takes empirical clarity to see the difference. This study aimed to determine the difference in the number of airborne operating room fluid before and after UV sterilization in RSUD Ratu Zalecha Martapura. This study used design of experiments (one group pre and post test design), Population in this research was amount of air of operating room at Ratu Zalecha Martapura Hospital. The sample of this research was the air space bacteria OK 1 Ratu Zalecha Martapura Hospital total operating room amounted to 5 rooms.. Data were analyzed used paired sample t-test. The results of this study indicate that there are significant differences before surgery after sterilization with postoperative 1 before sterilization $p$ value (0.015) $\leq$ nilai $\alpha(0.05)$. Advice for sterilization officers operating room are check UV rays effectivity, maintenance of UV lighting and sterilization process should be done after room sterilization.
\end{abstract}

Keywords : Air germ rate, UV sterilizer, Operating room

\begin{abstract}
Abstrak: Perbedaan Angka Kuman Udara Ruang Operasi Sebelum Dan Sesudah Sterilisasi UV Di RSUD Ratu Zalecha Martapura. Rumah sakit menjadi salah satu tempat terjadinya pencemaran lingkungan, gangguan kesehatan atau dapat menjadi tempat penularan penyakit. Ruang operasi merupakan ruangan yang berpotensi tinggi menyebabkan infeksi nosokomial di rumah sakit terutama infeksi luka operasi. Kualitas bakteriologis ruangan operasi bedah umum dan ruang inap, peneliti berasumsi bahwa ada variasi angka rasio yang berbeda pada tahapan hasil pengukuran laboratories. Sehingga diperlukan kejelasan secara empiris untuk melihat perbedaan tersebut. Penelitian ini bertujuan untuk mengetahui perbedaan angka kuman udara ruang operasi sebelum dan sesudah sterilisasi UV di RSUD Ratu Zalecha Martapura. Penelitian ini dengan menggunakan eksperimen (one group pre and post test design), Populasi dalam penelitian ini adalah jumlah kuman udara ruang operasi di Rumah Sakit Ratu Zalecha Martapura. Sampel penelitian ini adalah kuman udara ruang OK 1 Rumah Sakit Ratu Zalecha Martapura total ruangan operasi berjumlah 5 ruangan. Analisis data menggunakan uji statistik yaitu paired sample t-test. Hasil penelitian ini menunjukkan ada perbedaan signifikan sebelum operasi sesudah sterilisasi dengan sesudah operasi 1 sebelum sterilisasi $p$ value $(0.015) \leq$ nilai $\alpha(0.05)$. Saran bagi petugas sterilisasi ruang operasi adalah memeriksa keefektifan sinar UV, memelihara lampu UV, dan proses sterilisasi yang dilakukan sebaiknya setiap selesai operasi dilakukan sterilisasi ruangan.
\end{abstract}

Kata Kunci $\quad$ : Angka Kuman Udara, Sterilisasi UV, Ruang Operasi

\section{PENDAHULUAN}

Salah satu sasaran pembangunan kesehatan adalah lingkungan sehat termasuk lingkungan rumah sakit. Rumah sakit menjadi salah satu tempat terjadinya pencemaran lingkungan, gangguan kesehatan atau dapat menjadi tempat penularan penyakit [1]. Pemerintah 
Indonesia telah mengatur persyaratan kualitas udara di rumah sakit dalam Keputusan Menteri Kesehatan RI No.1204/MENKES/SK/X/2004 tentang persyaratan kesehatan lingkungan Rumah Sakit. Sebagai suatu institusi, rumah sakit memberikan pelayanan kesehatan dalam rangka mengobati dan menyembuhkan penderita, sehingga didapatkan kondisi yang sehat dan terbebas dari penyakit [2]. Ruang operasi merupakan ruangan yang berpotensi tinggi menyebabkan infeksi nosokomial di rumah sakit terutama infeksi luka operasi. Lingkungan ruang operasi beresiko tinggi yang bisa menjadi tempat yang mudah menularkan infeksi dari dan ke penderita, karena di ruang operasi ini terjadi pemajanan jaringan tubuh [3]. Rumah Sakit Umum Daerah Ratu Zalecha Martapura merupakan rumah sakit milik Pemerintah Kabupaten Banjar yang mempunyai tugas melaksanakan penyusunan dan pelaksanaan kebijakan daerah di bidang pelayanan kesehatan dalam rangka menyelenggarakan upaya kesehatan secara berdaya guna dan berhasil guna dengan mengutamakan upaya penyembuhan dan pemulihan yang dilaksanakan secara serasi dan terpadu serta upaya peningkatan pencegahan penyakit dan melaksanakan upaya rujukan. Data infeksi nosokomial dan kuman udara di RSUD Ratu Zalecha Martapura pada ruang operasi belum pernah ada dilaporkan atau diteliti tetapi tentang angka kuman lantai pada ruang operasi pernah dilakukan penelitian. Hasil penelitian (Mahmud, 2013) bahwa angka kuman lantai ruang operasi sebelum didesinfeksi $925 \mathrm{CFU} / \mathrm{m}^{2}, 15$ menit sesudah didesinfeksi $588 \mathrm{CFU} / \mathrm{m}^{2}, 60$ menit sesudah didesinfeksi $209 \mathrm{CFU} / \mathrm{m}^{2}$ dan 120 menit sesudah didesinfeksi 451 $\mathrm{CFU} / \mathrm{m}^{2}$. Suhu ruangan berkisar 27,4 $30^{\circ} \mathrm{C}$ dan kelembaban 81,8 - 88,6\%. Kemungkinan penyebab tingginya angka kuman lantai karena suhu serta kelembaban yang optimum untuk perkembangbiakan kuman dan tingginya kunjungan [4]. Berdasarkan hasil penelitian yang ditulis diatas, kualitas bakteriologis ruangan operasi bedah umum dan ruang inap, peneliti berasumsi bahwa ada variasi angka rasio yang berbeda pada tahapan hasil pengukuran laboratories. Sehingga diperlukan kejelasan secara empiris untuk melihat perbedaan tersebut, karena variasi perbedaan itu akan signifikan terhadap perlakuan pada objek dilokasi penelitian.

\section{BAHAN DAN CARA PENELITIAN}

Jenis penelitian bersifat eksperimental untuk mengetahui seberapa besar metode sterilisasi ultraviolet (uv) ruangan dengan angka kuman udara pada ruang operasi di RSUD Ratu Zalecha Martapura. Desain atau rancang bangun penelitian yang digunakan adalah one group pre and post test design, yaitu tidak ada pembanding (control), tetapi paling tidak sudah dilakukan observasi pertama (pretest) yang memungkinkan menguji perubahanperubahan yang terjadi setelah adanya eksperimen (program) [5]. Populasi : jumlah kuman udara ruang operasi di Rumah Sakit Ratu Zalecha Martapura. Sampel : kuman udara ruang OK 1 (Mayor/Bedah Umum) Rumah Sakit Ratu Zalecha Martapura. Analisis data menggunakan uji T-Test Terikat (Paired Sample T-Test), untuk mengetahui membandingkan 2 rata-rata yang berasal dari kelompok yang sama ( skala data : interval / ratio ).

\section{HASIL PENELITIAN DAN PEMBAHASAN}

Proses Sterilisasi UV Ruang OK.2 (Mayor/Bedah Umum)

Hari pertama

Operasi dilakukan $2 \mathrm{kali}$; operasi pertama dilakukan jam 09.40 wita dan operasi kedua dilakukan jam 11.20 wita; selesai operasi yang terakhir jam 12.00 wita dilakukan sterilisasi ruang dengan UV. Lampu UV untuk sterilisasi ruangan pada jam 13.00 wita sampai keesokan hari sebelum operasi dilakukan.

\section{Hari kedua}

Operasi dilakukan 5 kali; operasi pertama dilakukan jam 10.30 wita, operasi kedua dilakukan jam 12.10 wita, operasi ketiga dilakukan jam 13.40 wita, operasi keempat dilakukan jam 14.40 wita, operasi kelima dilakukan jam 15.30 wita; 
Luky Rinda Meiriana, Imam Santoso, Erminawati. Perbedaan Angka Kuman Udara Ruang Operasi Sebelum Dan Sesudah Sterilisasi UV Di RSUD Ratu Zalecha

Martapura

selesai operasi yang terakhir jam 16.00 wita, dilakukan sterilisasi ruang dengan UV. Lampu UV untuk sterilisasi ruangan pada jam 16.15 wita sampai keesokan hari sebelum operasi dilakukan.

\section{Hasil Pengukuran Suhu dan Kelembaban Pada Ruang Operasi}

Tabel 1. Hasil Pengukuran Suhu dan Kelembaban Ruang OK.2 (Mayor/Bedah Umum)

\begin{tabular}{|c|c|c|c|c|c|c|c|}
\hline \multirow[t]{3}{*}{ Titik Sampel } & \multicolumn{6}{|c|}{ Hasil Pengukuran $\left({ }^{0} \mathrm{C}\right)$} & \multirow[t]{3}{*}{ Standart $^{(*)}$} \\
\hline & \multicolumn{3}{|c|}{$\mathrm{H} 1$} & \multicolumn{3}{|c|}{$\mathrm{H} 2$} & \\
\hline & Sebelum & Sesudah 1 & Sesudah 2 & Sebelum & Sesudah 1 & Sesudah 2 & \\
\hline X1 & 25 & 25 & 25 & 29 & 27 & 29 & \multirow[t]{4}{*}{$19-24{ }^{0} \mathrm{C}$} \\
\hline $\mathbf{X} 2$ & 25 & 25 & 25 & 29 & 27 & 28 & \\
\hline $\mathbf{X 3}$ & 25 & 25 & 25 & 29 & 27 & 28 & \\
\hline Rata-Rata & 25 & 25 & 25 & 29 & 27 & 28,3 & \\
\hline Titik & \multicolumn{6}{|c|}{ Hasil Pengukuran (\%) } & \multirow[t]{7}{*}{ Standart $^{(*)}$} \\
\hline Sampel & \multicolumn{3}{|c|}{$\mathrm{H} 1$} & \multicolumn{3}{|c|}{$\mathrm{H} 2$} & \\
\hline & Sebelum & Sesudah 1 & Sesudah 2 & Sebelum & Sesudah 1 & Sesudah 2 & \\
\hline X1 & 50 & 55 & 55 & 60 & 50 & 40 & \\
\hline $\mathbf{X} 2$ & 50 & 55 & 55 & 60 & 50 & 40 & \\
\hline $\mathbf{X 3}$ & 50 & 55 & 55 & 60 & 50 & 41 & \\
\hline Rata-Rata & 50 & 55 & 55 & 60 & 50 & 40,3 & \\
\hline \multicolumn{8}{|c|}{ Keterangan: } \\
\hline $\mathrm{X} 1$ & \multicolumn{7}{|c|}{ : Titik pengambilan 1 (pintu masuk ruang operasi) } \\
\hline $\mathrm{X}^{2}$ & \multicolumn{7}{|c|}{ : Titik pengambilan 2 (meja Operasi) } \\
\hline $\mathrm{X}^{3}$ & \multicolumn{7}{|c|}{ : Titik pengambilan 3 (meja peralatan operasi) } \\
\hline $\mathrm{H} 1$ & \multicolumn{7}{|c|}{ : Hari pertama } \\
\hline $\mathrm{H}_{2}$ & \multicolumn{7}{|c|}{ : Hari kedua } \\
\hline
\end{tabular}

Hasil Pemeriksaan Angka Kuman Udara Pada Ruang Operasi

Hasil pemeriksaan laboratorium angka kuman udara di ruang OK.2 (Mayor/Bedah Umum) sebelum dan sesudah sterilisasi UV Gambar 3.

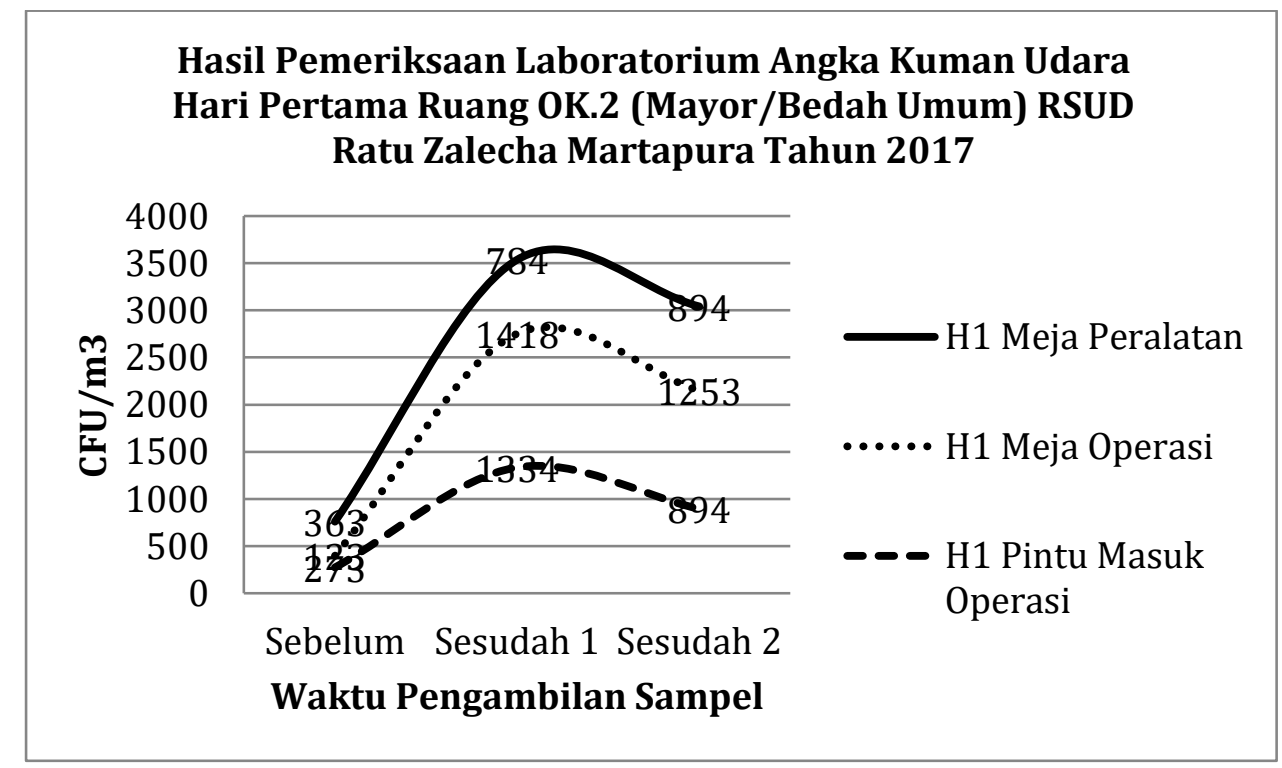




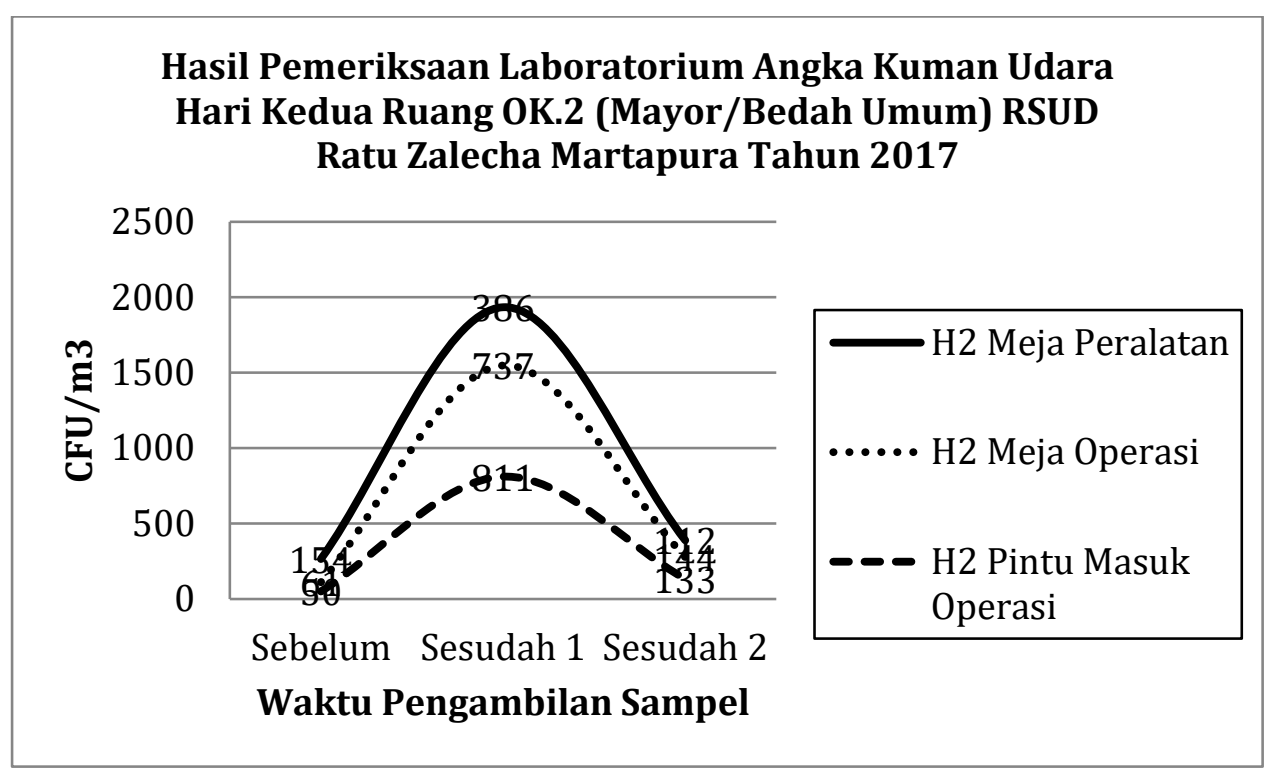

Gambar 3. Grafik Hasil Pemeriksaan Laboratorium Angka Kuman Udara Ruang OK.2 (Mayor/Bedah Umum) RSUD Ratu Zalecha Martapura Tahun 2017

\section{Hasil Uji Statistik}

Setelah dilakukan analisis dengan menggunakan uji Dependent Sample T Test didapatkan hasil bahwa nilai sig pada variabel sebelum dengan sesudah $1 p$ value (0.015) kurang dari nilai $\alpha(0.05)$ yang berarti ada perbedaan signifikan Sebelum antara Sesudah 1. Sedangkan antara sebelum-sesudah $2 p$ value $(0,079)$ lebih dari nilai $\alpha(0.05)$ dan anatar sesudah 1sesudah $2 p$ value $(0,077)$ lebih dari nilai $\alpha$ (0.05) yang berarti tidak ada perbedaan signifikan sebelum dengan sesudah 2 , dan sesudah 1 dengan sesudah 2 .

\section{Analisis Proses Sterilisasi}

Sterilisasi ruangan operasi RSUD Ratu Zalecha yang digunakan adalah sinar Ultraviolet dengan proses sebagai berikut: Hari pertama, selasa 13 Juni 2017 proses sterilisasi ruangan dilakukan pada jam 12.00 wita sampai keesokan hari sebelum operasi hari ke dua dilakukan. Kegiatan operasi dihari pertama ada 2 kali operasi, dan berakhir pada jam 11.00 wita. Hari kedua, rabu 14 Juni 2017 proses sterilisasi ruangan dilakukan pada jam 16.00 wita sampai keesokan hari sebelum operasi hari selanjutnya dilakukan. Kegiatan operasi dihari kedua ada 5 kali operasi, dan berakhir pada jam 15.05 wita.

Hasil penelitian Liena Sofiana dan Dwi Wahyuni (2014) Pengaruh Sterilisasi Ozon Terhadap Penurunan Angka Kuman Udara Di Ruang Rawat Inap Di Rumah
Sakit Umum PKU Muhammadiyah Bantul 2014 mengatakan bahwasannya sterilisasi ozon tidak cukup efektif dalam penurunan angka kuman udara ruangan, akan tetapi ada metode sterilisasi dengan menggunakan sinar UV dapat menurunkan angka bakteri kontaminan udara. Terdapat perbedaan jumlah koloni bakteri kontaminan udara sebelum dan sesudah sterilisasi ultraviolet di ruang operasi RSUD Banjarbaru [6]. Sterilisasi yang dilakukan di ruang OK.2 (Mayor/Bedah Umum) yaitu menggunakan sterilisasi sinar UV sudah berfungsi cukup baik, hanya saja belum ada diukur tentang keefektifannya. Sinar UV umumnya digunakan untuk membantu mengurangi kontaminasi mikroba di udara dan pemusnahan selama proses di lingkungan. Sinar yang bersifat membunuh mikroorganisme diproduksi oleh lampu kabut merkuri yang dipancarkan secara efektif pada UV menembus dinding sel dengan langsung mengenai DNA dan inti sel sehingga mikroba mengalami mutasi [7].

\section{Analisis Hasil Pengukuran Suhu dan Kelembaban Pada Ruang Operasi \\ Hasil pengukuran suhu ruang} operasi di RSUD Ratu Zalecha Martapura pada saat AC dalam keadaan hidup, ratarata yang didapatkan adalah $25^{\circ} \mathrm{C}$ (hari pertama), $28,1^{\circ} \mathrm{C}$ (hari kedua). Hasil pengukuran kelembaban ruang operasi 
di RSUD Ratu Zalecha Martapura pada saat AC dalam keadaan hidup, rata-rata yang didapatkan adalah 53\% (hari pertama), $53,3 \%$ (hari kedua).

Kondisi suhu yang tidak memenuhi standart dapat menyebabkan tingginya angka kuman udara karena suhu optimum perkembangbiakan bakteri sekitar $37^{\circ} \mathrm{C}$ yang juga adalah suhu tubuh manusia. Oleh karena itu suhu tubuh manusia merupakan suhu yang baik untuk pertumbuhan beberapa bakteri pathogen, Mikroba perusak dan pathogen umumnya dapat tumbuh pada kisaran suhu $4^{\circ} \mathrm{C}-66^{\circ} \mathrm{C}$ [8]. Berdasarkan hasil pengukuran suhu ruang operasi di RSUD Ratu zalecha Martapura pada saat AC dalam keadaan hidup, masih belum memenuhi standart kesehatan lingkungan.

\section{Analisis Hasil Pemeriksaan Angka Kuman Udara}

Berdasarkan hasil pemeriksaan laboratorium, ternyata jumlah angka kuman udara ruang OK.2 (Mayor/Bedah) di RSUD Ratu Zalecha Martapura pada pengambilan sampel udara hari pertama dan hari kedua tidak memenuhi standart kesehatan lingkungan.

Jumlah angka kuman udara hari pertama dan kedua sangat tinggi, dengan perlakuan pengambilan sampel sebelum operasi sesudah sterilisasi didapatkan hasil angka kuman udara lebih rendah daripada hasil pengambilan sampel sesudah operasi 1 sebelum sterilisasi. Sedangkan pengambilan sampel sesudah operasi 1 sebelum sterilisasi didapatkan hasil sangat tinggi daripada hasil pengambilan sesudah operasi 2 sebelum sterilisasi. Proses pertumbuhan mikroba kemungkinan mempengaruhi tinggi rendahnya angka kuman udara di ruang operasi. Berdasarkan hasil secara sistematis pertumbuhan mikroba digambarkan dalam bentuk grafik [9]. Terbagi atas beberapa tahap, dimana tahap A-B disebut tahap istirahat (lag phase). Pada keadaan ini bila mikroba tersebut dimasukkan kedalam media, akan hidup terus, tetapi belum dapat berkembang biak. Tahap ini merupakan masa persiapan bagi mikroba tersebut untuk melangsungkan metabolisme pada tahap berikutnya, dan bila metabolisme sudah siap baru terjadi pembiakan. Tahap B-C disebut tahap tumbuh (accelerate phase) yaitu tahap terjadinya pembelahan. Bila bahan makanan cukup dan lingkungan hidupnya optimum atau (suhu dan $\mathrm{pH}$ ), mikroba akan bertambah dengan cepat sekali. Kecepatan pertumbuhan tersebut merupakan fungsi eksponensial dengan waktu. Tahap C-D disebut tahap tumbuh panas (log phase) dimana kurvanya merupakan fungsi eksponensial dengan waktu. Hubungan antara log jumlah mikroba yang masih hidup dengan waktu merupakan garis lurus. Tahap D-E disebut tahap tumbuh reda (decelerate phase). Pada tahap ini pertumbuhan mikroba menurun karena beberapa makanan yang tersedia berkurang atau karena adanya racun hasil metabolismenya sendiri, sehingga terjadi pembelokan pada kurva pertumbuhan. Tahap E-F disebut tahap tumbuh tetap (stationary phase) dimana jumlah mikroba yang baru dan yang mati seimbang, sehingga jumlahya juga seimbang. Tahap F dan seterusnya disebut tahap kematian (death phase) dimana jumlah mikroba yang mati jauh lebih besar daripada yang baru [9]. Selain proses pertumbuhan mikroba, jeda waktu setelah proses sterilisasi, kemungkinan juga mempengaruhi tinggi rendahnya angka kuman udara di ruang operasi [7].

\section{Analisis Bivariat}

Berdasarkan hasil statistik dapat dikatakan bahwa ada perbedaan sebelum operasi setelah sterilisasi dengan sesudah operasi 1 sebelum disterilisasi UV dihari pertama dan kedua. Sedangkan hasil statistik sebelum operasi sesudah sterilisasi dengan sesudah operasi 2 sebelum sterilisasi dan sesudah operasi 1 sebelum disterilisasi dengan sesudah operasi 2 sebelum disterilisasi dihari pertama dan kedua dapat dikatakan bahwa tidak ada perbedaan.

Proses sterilisasi sangat berpengaruh terhadap penurunan angka kuman udara ruang operasi [7]. Diketahui proses sterilisasi ruangan dari hari sebelum pengambilan sampel senin 12 
Juni 2017 sampai hari pengambilan sampel hari pertama, selasa 13 Juni 2017 waktu proses sterilisasi ruangan yaitu 17 jam 15 menit. Sedangkan, diketahui proses sterilisasi ruangan dari hari pertama pengambilan sampel Selasa 13 Juni 2017 sampai hari pengambilan sampel hari kedua Rabu 14 Juni 2017 waktu proses sterilisasi ruangan yaitu 21 jam 55 menit. Sehingga, didapatkan hasil angka kuman udara dihari kedua lebih rendah dari hari pertama.

Jeda waktu setelah proses sterilisasi, kemungkinan juga mempengaruhi tinggi rendahnya angka kuman udara di ruang operasi. Menurut Gorra S, (2014) ruang operasi digunakan secara ideal 4,5 jam setelah ruangan disterilisasi. Efektivitas penurunan angka kuman dengan menggunakan sinar UV pada ruang operasi yaitu 4-5 jam. Apabila sterilisasi dilakukan selama lebih dari 5 jam maka angka kuman akan kembali naik [10].

\section{KESIMPULAN DAN SARAN}

Proses Sterilisasi UV Ruang OK.2 (Mayor/Bedah Umum) sesudah operasi dilakukan sterilisasi ruangan dengan UV sampai keesokan harinya sebelum operasi dilakukan

Suhu di ruang OK.2 (Mayor/Bedah) rata-rata yang didapatkan adalah $250 \mathrm{C}$ (hari pertama), 28,10C (hari kedua). Sedangkan kelembaban rata-rata yang didapatkan adalah 53\% (hari pertama), $53,3 \%$ (hari kedua).

Jumlah rata-rata yang didapatkan angka kuman udara pada hari pertama sebelum operasi setelah sterilisasi adalah $253 \mathrm{CFU} / \mathrm{m} 3$, sesudah operasi sebelum sterilisasi adalah 1.178,67 CFU/m3, sebelum operasi sebelum disterilisasi adalah $1.007 \mathrm{CFU} / \mathrm{m} 3$. Sedangkan pada hari kedua sebelum operasi setelah sterilisasi adalah 88,33 CFU/m3, sesudah 1 operasi sebelum sterilisasi adalah 644,67 $\mathrm{CFU} / \mathrm{m} 3$, sesudah operasi 2 sebelum disterilisasi adalah 129,67 CFU/m3 . Jumlah angka kuman udara tidak memenuhi syarat kesehatan.
Terbukti secara statistik ada perbedaan yang signifikan angka kuman udara sebelum operasi setelah sterilisasi dengan sesudah operasi pertama sebelum disterilisasi UV pada pertama dan kedua.

\section{KEPUSTAKAAN}

1. Haryono. 2010. Infeksi Nosokomial Rumah Sakit. Jakarta: Renika.

2. Kepmenkes RI. 2004. Keputusan Menteri Kesehatan Republik Indonesia Nomor 1204/MENKES/SK/X/2004 Tentang Persyaratan Kesehatan Lingkungan Rumah Sakit Direktorat Jenderal Pemberantasan Penyakit Menular dan Penyehatan Lingkungan.

3. Supryantoro. 2012. Pedoman Teknis Prasarana Sistem Tata Udara pada Bangunan Rumah Sakit. Kementerian Kesehatan RI Direktorat Bina Pelayanan Penunjang Medik dan Sarana Kesehatan. Jakarta.

4. Mahmud, A. 2013. Angka Kuman Lantai Ruang Perawatan Bedah Di Rumah Sakit Umum Ratu Zalecha Martapura Tahun 2013, Karya Tulis Ilmiah, Poltekkes Banjarmasin

5. Notoatmodjo, S. 2012. Metode Penelitian Kesehatan. Jakarta : Rineka Cipta

6. Liena Sofiana, Dwi Wahyuni. 2014. Pengaruh Sterilisasi Ozon Terhadap Penurunan Angka Kuman Udara Di Ruang Rawat Inap Di Rumah Sakit Umum PKU Muhammadiyah Bantul 2014. Jurnal Kesehatan Masyarakat, Universitas Ahmad Dahlan, Yogyakarta

7. Gorra S, dkk, 2014. Metode Sterilisasi Radiasi Ultraviolet (UV), Lampung

8. Dwidjoeseputro, 1998. Dasar-Dasar Mikrobiologi. Unipress: Jakarta

9. Fardiaz, S. 1992. Mikrobiologi Pangan 1. PT Gramedia Pustaka Utama, Jakarta

10. Santoso, I, dkk. 2007. Pengaruh Sinar Ultra Violet Terhadap Penurunan Koloni Kuman Udara Pada Ruang Operasi Beberapa RSUD di Kalsel. Jurnal Kesehatan, Banjarbaru 